\title{
A clinico-pathological study of malignant breast lump in a tertiary care hospital in Kosi region of Bihar, India
}

\author{
Shambhu Kumar Singh ${ }^{1}$, Deepak Pankaj ${ }^{1}$, Rajesh Kumar $^{2}, \operatorname{Rayaz}_{\text {Mustafa }}{ }^{1}$
}

\author{
${ }^{1}$ Department of General Surgery, Katihar Medical College, Katihar, Bihar, India \\ ${ }^{2}$ Department of Pathology, Katihar Medical College, Katihar, Bihar, India
}

Received: 09 October 2015

Revised: 17 October 2015

Accepted: 04 November 2015

\author{
*Correspondence: \\ Dr. Deepak Pankaj, \\ E-mail: drdeepakpankaj@gmail.com
}

Copyright: ( ) the author(s), publisher and licensee Medip Academy. This is an open-access article distributed under the terms of the Creative Commons Attribution Non-Commercial License, which permits unrestricted non-commercial use, distribution, and reproduction in any medium, provided the original work is properly cited.

\begin{abstract}
Background: Breast cancer has captured attention of surgeons throughout the ages with its uncertain cause. Despite centuries of meandering and scientific enquiry, breast cancer is still one of the most dreaded human diseases. The breast is a complex structure and any unnatural change affects the body and psyche of the person. The aim of this study was to observe age distribution, clinical signs and symptoms and pathology of malignant breast lump and draw a correlation between clinical and histological diagnosis of patients presenting with breast lump.

Methods: Seventy six (76) cases of diagnosed malignant breast lump out of a total of 200 cases were included in this study. These cases were selected among patients visiting outdoor clinic of department of General Surgery in Katihar Medical College, Katihar. The selected cases belonged to different etiology, age group and sex.

Results: Maximum number of malignant tumours was encountered in the 5th decade of age group of patients, followed by in 4th decade. All cases studied were females except 2 cases which were male. The commonest sign and symptoms of presentation was painless lump in the breast followed by painful mass in the breast along with associated features of ulceration of the skin, retraction of nipple and nipple discharge. Histologically, malignant tumours were maximally observed as infiltrating scirrhous carcinoma, followed by medullary carcinoma \& papillary carcinoma.

Conclusions: Breast cancer is a common cancer worldwide with varied presentation. Multimodality treatment approach is required for malignant breast lump which has shown improvement in both loco regional control and survival.
\end{abstract}

Keywords: Breast, Histopathology, Infiltrating carcinoma of breast, Malignancy, Surgery

\section{INTRODUCTION}

Breasts are an important feature of female anatomy and an integral part of reproductive system. It is a glandular organ influenced by hormones in females and composed of various structures giving rise to different types of lesions and lumps. ${ }^{1}$ These lesions of breast can be of various types ranging from inflammatory to benign to malignant with some lesions being common in young females while other being common in elderly to older age group. Of all the breast disorders, pain is the first common presentation with palpable breast lump being the second most common presentation. ${ }^{2}$ Breast cancer is one of the commonest malignant tumours in the world and is one of the leading causes of death due to cancer in women. ${ }^{3}$ It is the leading cause of death in women aged between 35 to 54 years. One in eight women are diagnosed with breast cancer during their life time. ${ }^{4}$ In India the incidence of breast cancer is low but rising. India is a sub - continent with wide ethnic, cultural, 
religious and economic diversity with variation in healthcare infrastructure. With rising incidence and awareness, breast cancer is the commonest cancer in urban Indian females and the second most commonest in rural Indian females. ${ }^{5}$ Over 100,000 new breast cancer patients are estimated to be diagnosed annually in India. ${ }^{6}$ As per ICMR -PBCR data, breast cancer is the commonest cancer among women in urban registries of Delhi, Mumbai, Ahmedabad, Kolkata and Trivandrum where it accounts for more than $30 \%$ of all cancers in females. ${ }^{7}$ It is also estimated that of all the reported cases of breast cancer, $50-70 \%$ of cases are advanced at presentation in India. ${ }^{8}$ If left untreated, the mean survival is about 3 years after clinical presentation and 5 year survival rate is less than $20 \%$. $^{9}$ This present study was undertaken with a view to see trends in various types of breast lump with special emphasis on malignant lesions in this part of Kosi region of Bihar for better understanding and comprehensive study of the disease in all parameters. The need of the hour in cases of breast cancer is health awareness, promotion of early detection by organizations in health sector and providing comprehensive multimodality approach in a protocol based manner. Also there is a need for providing support to breast cancer patients in their management as well as screening of the disease and rehabilitation of the patients.

\section{METHODS}

After prior approval from the Institutional Ethics Committee (IEC), a prospective clinico-pathological study on 200 cases of breast lump was carried out at the department of Surgery, Katihar Medical College \& Hospital, Katihar over a period of three years. Out of which, 76 cases of malignant lump was found and included in this study whose diagnosis was confirmed histologically. Other benign and acute cases were excluded from the study.

Methods of collection of data:

1. Detailed history taking

2. Clinical Examination

3. Routine Laboratory investigations

4. Relevant special investigation

5. Histological examination of the tissue was undertaken \& tissue was taken from the breast by biopsy, local excision of the lump or specimen from the mastectomies.

\section{RESULTS}

In this study, 76 cases of malignant breast lump were observed. In those 76 cases, majority was females 74 $(97.37 \%)$ and number of males was $2(2.63 \%)$. According to religion, number of Muslim patients was more that is $40(52.63 \%)$ as compared to Hindu patients $36(47.37 \%)$.

Maximum no. of malignant cases was encountered in the age group of $41-50$ yrs. $\left(5^{\text {th }}\right.$ decade) i.e. $50 \%$, and then in $4^{\text {th }} \& 6^{\text {th }}$ decades with percentage being $31.57 \%$ and $10.52 \%$ respectively (Table 1 ).

Table 1: Distribution of malignant breast tumours according to age.

\begin{tabular}{|lll|}
\hline Age in years & No. Of cases & Percentage \\
\hline $20-30$ & 6 & 7.89 \\
\hline $31-40$ & 24 & 31.57 \\
\hline $41-50$ & 38 & 50.00 \\
\hline $51-60$ & 8 & 10.52 \\
\hline $61 \&$ above & - & - \\
\hline Total & 76 & 100.00 \\
\hline
\end{tabular}

According to duration, maximum number of cases, $42.11 \%$ was of duration between 6 months to 1 year, followed by tumours of less than 6 months duration $(36.84 \%)$. Least number of cases i.e. $7.89 \%$ was seen in those whose duration was between 1.5 to 2 years (Table 2).

Table 2: Distribution of malignant lump according to duration of illness.

\begin{tabular}{|ll|}
\hline Duration & Malignant tumours \\
\hline$<6$ months & $28(36.84 \%)$ \\
\hline 6 months -1 year & $32(42.11 \%)$ \\
\hline 1year -1.5 years & $10(13.16 \%)$ \\
\hline 1.5 years -2 years & $6(7.89 \%)$ \\
\hline
\end{tabular}

Painless mass was the most common symptom found in maximum number of patients i.e. $62(60.78 \%)$ of cases. Painful mass was present in $14(13.73 \%)$ patients. Ulceration, retraction and nipple discharge was present in 15 (14.71\%), 7 (6.86\%) and 4 (3.92\%) patients respectively. Some patients presented with more than one symptom, the percentage of which are as follows (Table 3).

According to parity, 36 patients $(47.37 \%)$ who had more than 3 up to 6 children presented with malignant breast lump followed by 28 patients $(36.84 \%)$ who had up to 3 children. Least number of cases, 4 (5.26\%) were present in those who had no children (Table 4).

Table 3: Frequency of various modes of presentation of malignant breast lump.

\begin{tabular}{|ll|}
\hline Signs \& Symptoms & Number of cases \\
\hline Painless mass in breast & $62(60.78 \%)$ \\
\hline Ulceration & $15(14.71 \%)$ \\
\hline Painful mass & $14(13.73 \%)$ \\
\hline Retraction & $7(6.86 \%)$ \\
\hline Nipple discharge & $4(3.92 \%)$ \\
\hline
\end{tabular}


Table 4: Distribution of malignant breast lump according to parity.

\begin{tabular}{|ll|}
\hline Parity & Malignant tumours \\
\hline No children & $4(5.26 \%)$ \\
\hline Up to 3 children & $28(36.84 \%)$ \\
\hline$>3$ up to 6 children & $36(47.37 \%)$ \\
\hline$>6$ children & $8(10.53 \%)$ \\
\hline
\end{tabular}

Table 5: Distribution of lump according to side and quadrant.

\begin{tabular}{|lll|}
\hline Site \& Quadrant & Right Breast & \multicolumn{1}{c|}{ Left Breast } \\
\hline UOQ & $16(21.05 \%)$ & $20(26.31 \%)$ \\
\hline LOQ & $8(10.53 \%)$ & $2(2.63 \%)$ \\
\hline UIQ & $8(10.53 \%)$ & $8(10.53 \%)$ \\
\hline LIQ & - & $2(2.63 \%)$ \\
\hline Central & $4(5.26 \%)$ & $8(10.53 \%)$ \\
\hline Total & $36(47.37 \%)$ & $40(52.63 \%)$ \\
\hline $\begin{array}{l}\text { UOQ - upper outer quadrant; LOQ - lower outer quadrant; UIQ } \\
\text { - upper inner quadrant; LIQ - lower inner quadrant }\end{array}$
\end{tabular}

According to side and quadrant, more lesions were seen in Left breast $40(52.63 \%)$ as compared to Right breast $36(47.37 \%)$. In both of the breast, upper outer quadrant was the most common side involved (Table 5).

Table 6: Histopathological examination showing types of malignant lump.

\begin{tabular}{|ll|}
\hline Lesions & Number of cases \\
\hline Scirrhous & $60(78.94 \%)$ \\
\hline Medullary & $8(10.53 \%)$ \\
\hline Colloid & $4(5.26 \%)$ \\
\hline Papillary & $4(5.26 \%)$ \\
\hline
\end{tabular}

According to histopathological report, most common type of malignancy observed was scirrhous carcinoma i.e. $78.94 \%$, followed by medullary carcinoma i.e. $10.52 \%$. Colloid and Papillary variant of breast carcinoma was present in $5.26 \%$ of cases each (Table 6).

Also, according to size, 40 patients had size of lump more than $5 \mathrm{~cm}(52.63 \%), 34$ patients had size of lump between $2.5 \mathrm{~cm}$ up to $5 \mathrm{~cm}(44.74 \%)$ and 2 patients had size of lump less than $2.5 \mathrm{~cm}(2.63 \%)$. Lymph node involvement was seen in 32 cases $(42.11 \%)$, out of which axillary lymph node involvement was seen in 28 cases $(36.84 \%)$ and supraclavicular lymph node involvement was seen in 4 cases $(5.26 \%)$. No lymph node involvement was seen in 44 cases $(57.89 \%)$.

\section{DISCUSSION}

Breast cancer management has been a major challenge to surgeons in developing countries, principally due to the lack of advanced technology and late presentation of patients to the hospital. ${ }^{10}$ The incidence of malignant growth amongst the breast lesions is fairly common with more number of cases being detected in recent years and so it warrants the need for detecting out the morbid pattern of the tumour. Breast cancer kills 376000 women a year worldwide and there are about 900000 new case annually with increasing incidence in most parts of the world and especially developing country where it is almost as common as cervical cancer, the leading female cancer in developing world. ${ }^{11}$ Out of 76 cases of malignant breast lump, $74(97.37 \%)$ were females and 2 $(2.63 \%)$ were males. Numbers of Muslim patients were more than the Hindu patients in the present study in cases of malignant lump. No other religions reported any cases. But religion does not seem to have any bearing on any other clinical and pathological variables of breast cancer patients. $^{12}$

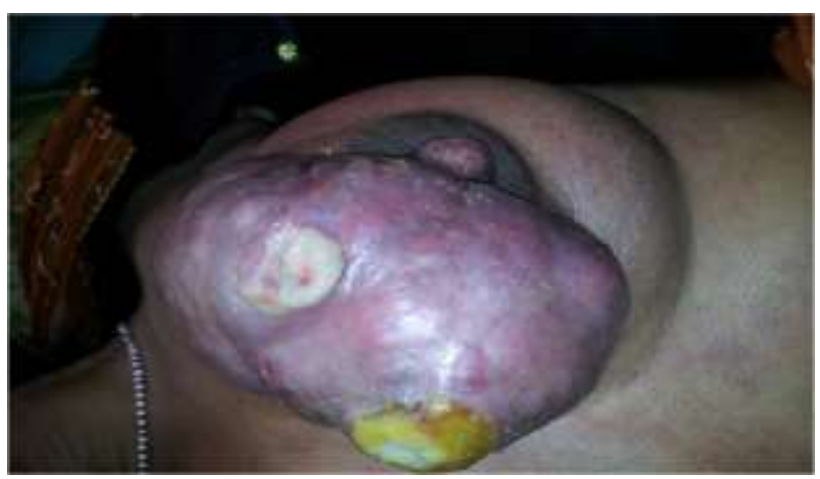

Figure 1: Malignant breast lump with ulceration and fungation.

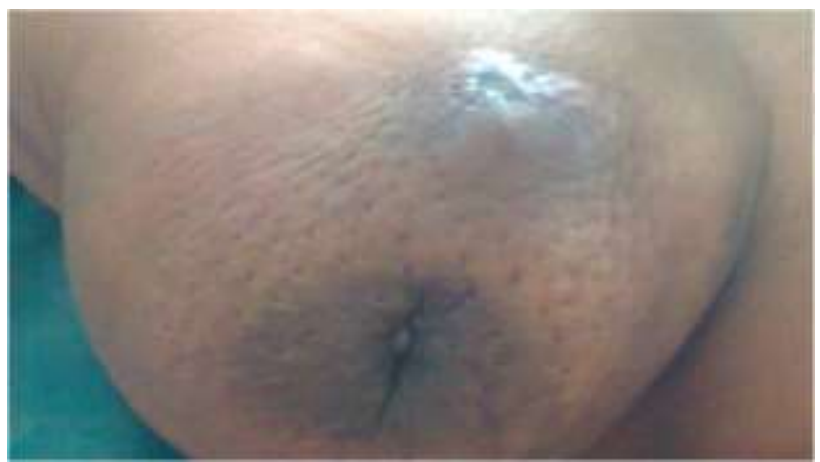

Figure 2: Malignant breast lump with Peau d' orange appearance of skin.

In the present series, the maximum incidence of malignant tumour were observed in the age group of $41-$ 50 yrs. $(50 \%)$ which is an agreement with the observation of Hankey BF et al. ${ }^{13}$ The mean age of the patients in this series was 46.6 years, a similar finding to the observation of Mabula JB et al where the mean age of breast cancer patients was 45 years. ${ }^{14}$ This is lower than the age reported in western countries where the median age at diagnosis is in the sixth decade of life. ${ }^{3,15,16}$ This shows that there is a difference in mean age of patients of breast carcinoma in developed and the developing nation. In the present study, maximum no. of patient of 
malignant tumour reported within a year i.e. $42.11 \%$ of patients reported within 6 months to 1 year of onset of symptoms followed by $36.84 \%$ of patients who presented within 6 months from onset of symptoms. Only $7.89 \%$ of patients presented late between 1.5 to 2 years. Even Bloom HJG in his series of 250 patients observed that according to duration of symptoms, maximum patients in that series i.e. $28.8 \%$ reported within one year of onset of symptoms followed by $26.4 \%$ within 1 to 2 years. This early reporting in case of malignant breast lump clearly suggests increasing awareness of patients about the disease in the developing nation over the period of time. ${ }^{17}$

In the present study, by far the most common presenting feature was painless mass in the breast $(60.78 \%)$ followed by painful mass $(13.73 \%)$ and associated features like ulceration of the skin, retraction of nipple and nipple discharge.

In the present series, the brunt of the breast lump was observed in the ladies having children between 3 to 6 . Out of 76 patients having malignant breast tumour, maximum no. $47.37 \%$ of patients had more than 3 up to 6 children followed by up to 3 children $(36.84 \%)$ and $5.26 \%$ had no children while $10.53 \%$ had more than 6 children. It has been known since longtime, that marriage and sexual function had tremendous influence in the development of the breast cancer. Macmohan B et al reported higher incidence of breast cancer in nulliparous women but an inverse correlation of breast cancer incidence with increasing parity has been repeatedly demonstrated. ${ }^{18}$ The most acceptable explanation for higher incidence of breast cancer in multipara is the fact that women of this part of country marry early \& become mother early and only a very few cases are sterile. However, this observation warrants further study of this nature.

Out of 76 patients of carcinoma of the breast, 40 $(52.63 \%)$, patients had left breast involvement whereas $36(47.37 \%)$ patients had right breast involvement. This observation fully confirms to the observations of Agrawal GP et al and Tulinius $\mathrm{H}$ et al who also observed increased incidence of breast cancer on left side with the latter reporting $13 \%$ increased incidence of carcinoma breast to left side. ${ }^{19,20}$ Out of 76 malignant breast tumours in present study, 36 cases $(47.36 \%)$ were seen in upper outer quadrant followed by upper inner quadrant 16 cases (21.06\%), lower outer quadrant 10 cases $(13.15 \%) \&$ central region 12 cases $(10.52 \%)$, in that order. This data is similar to the data obtained by Muqtadir et al and Mudholkar et al who reported $53.03 \%$ and $42.05 \%$ of involvement of upper outer quadrant of breast. ${ }^{21,22}$ Maximal involvement of upper outer quadrant as observed in the present study was also in agreement with the results reported by Darbre. ${ }^{23}$ The explanation for the predilection for the cancer in the upper outer quadrant lies in the fact that lymphatic drainage of the breast in this region is poor because of inadequate support and greater amount of target epithelial tissue in that region.
In the present series all cases of malignant growth were of carcinoma of the breast. Infiltrative carcinoma with fibrosis (scirrhous) was the commonest variety constituting $78.94 \%$ of the malignant lesions. Usually designated as scirrhous, it showed varying degree of fibrosis \& infiltration with cords or groups of polyhedral or spindle cells with hyperchromatic unclei. An incidence of more than $75 \%$ of scirrhous carcinoma had been reported in the recent study by Muqtadir et al and Mudholkar et al who reported $78.79 \%$ and $88 \%$ of involvement as scirrhous carcinoma. ${ }^{21,22}$

$10.53 \%$ of cases belonged to medullary carcinoma group in which fibrous tissue was scanty \& groups of round or polyhedral cells with vesicular nuclei and abundant cytoplasm formed the characteristic picture of the lesion. An incidence of $8.6 \%$ of cases of medullary carcinoma was reported by Haque et al in cases of malignant breast lump. Also 4 cases of papillary carcinoma and colloid carcinoma $(5.26 \%)$ was seen in the present study, in which there were papillary growths, cells showing considerable irregularity in, size \& shape of the nuclei and hyper chromatic nuclei. Haque et al observed $1.1 \%$ incidence of papillary carcinoma which is slightly lower than the incidence in the present series. ${ }^{24}$

The maximum number of lymph nodes involved was the axillary group of lymph nodes followed by two cases of right supraclavicular lymph nodes. This is in agreement with the observations of other workers.$^{25,26}$ Axillary node is the commonest node to be involved in cases of malignant breast lump but involvement of supraclavicular lymph nodes or any other contralateral lymph nodes represents advanced nature of the disease.

\section{CONCLUSION}

Understanding the risk factors for the development of breast carcinoma is important as it provides clues to the pathogenesis and identifies patients likely to benefit from reduction of risk factors. Although breast cancer can develop in both genders, women are at greatly increased risk and breast cancer in men is uncommon. Staging of breast cancer is determined prior to any treatment to categorize patient into risk categories that defines prognosis and guides recommendations for treatment. Breast cancer treatment in modern era involves both local and regional control (surgery and radiation therapy) in addition to medical therapy for systemic manifestations.

Funding: No funding sources

Conflict of interest: None declared

Ethical approval: The study was approved by the institutional ethics committee

\section{REFERENCES}

1. Jain SB, Jain I, Srivastava J, Jain B. A clinicopathological study of breast lumps in patients presenting in surgery OPD in a referral hospital in 
Madhya Pradesh, India. Int J Current Microbiol App Sci. 2015;4(8):919-23.

2. Kumar A, Vohra LS, Bhargava K, Reddy PS. Investigation of Breast Lump, an evaluation. MJAPI. 1999;55:299-302.

3. Ikpatt OF, Kuopoo I, NdomaEgbe R \& Collen Y. Breast cancer in Nigeria and Finland: epidemiological, clinical and histological comparison. Anticancer Research. 2002;22:3005-12.

4. Jemal A, Bray F, Canter MM, Ferlay J. Global Cancer Statistics. LA Cancer J Clin. 2011;61(2):6990.

5. National Cancer Registry Program. Ten years consolidated report of the Hospital based Cancer Registries, 1984-1993, an assessment of the burden and care of Cancer Patients. Indian Council of Medical Research. New Delhi, 2001.

6. Agrawal G, Pradeep PV, Agrawal V, Yip CH, Cheung PS. Spectrum of breast cancer in Asian women. World J Surg. 2007;31:1031-40.

7. National Cancer Registry Programme: Consolidated report of the Hospital based Cancer Registries, 1990-1996. Indian Council of Medical Research. New Delhi, 2001.

8. Chopra R. The Indian Scene. Journal of Clinical Oncology. 2001;19(18 Suppl):106S-11S.

9. Baum M. Modern concept of natural history of breast cancer: A guide to design and publication of trials of the treatment of breast cancer. Eur J Cancer. 2013;49(1):60-4.

10. Kene TS, Odigie VI, Yusufu LMD, Shehu SM \& Kase JT. Pattern of presentation and survival of breast cancer in a Teaching Hospital in North Western Nigeria. Oman Medical Journal. 2010;25:104-7.

11. The State of World Health. The World Health report 1997-Conquering suffering, enriching humanity. World Health Forum. 1997;18.

12. Paymaster TC, Gamgadharan P. Cancer in Parsi community of Bombay. Int J Cancer. 1970;5:426-31

13. Hankey BF, Miller B, Curtis R, Kosary C. Trends in breast cancer in younger women in contrast to older women. J Natl Cancer Inst Monogr. 1994;(16):7-14.

14. Mabula JB, Mabula DM, Chalya PL. Stage at diagnosis, clinicopathological and treatment patterns of breast cancer at Bugando Medical Centre innorth- western Tanzania. Tanzania Journal of Health Research. 2012;14(4):1-14.

15. Fregene A, Newman LA. Breast cancer in subSaharan Africa: how does it relate to a breast cancer in African-American women Cancer. 2005;103:1540-50.

16. Awadelkarim KD, Arrizi C, Elamin EOM. Pathological, clinical and prognostic characteristics of breast cancer in Central Sudan versus Northern Italy: implications for breast cancer in Africa. Histopathology. 2008;52:445-56.

17. Bloom HJG, Richardson WW, Harries EJ. Natural history of untreated breast cancer. $\mathrm{Br}$ Med $\mathrm{J}$. 1962;2(5299):231-21.

18. Macmohan B, Cole P, Lin TM. Age at first birth and breast cancer risk. Bull Wld Hlth Org. 1970;43:20921.

19. Aggrawal GP, Jain SP, Joshi DC. Carcinoma of Male breast. J Ind Med Assoc. 1964;43:3-61.

20. Tulinius H, Sigvaldason H, Olafsdottir G. Left and right sided breast cancer. Pathol Res Pract. 1990;186(1):92-4.

21. Muqtadir AMA, Shaikh JM, Anagha VS, Dawle AV. Clinical profile and outcome of breast cancer at tertiary care hospital in rural Maharashtra. An observational study. Int M Jour. 2015;2(4):238-40.

22. Mudholkar VG, Kawade SB, Mashal SN. Histopathological study of neoplastic lesions of breast. Indian Medical Gazette. 2012:353-64.

23. Darbre PD. Recorded quadrant increase of female breast in Great Britain suggests disproportionate increase in upper outer quadrant of breast. Anticancer Res. 2005;25(3c):2543-50.

24. Haque R, Tyagi SP, Khan MH, Gahlaut YVS. Breast lesions. A clinicopathological study of 200 cases of breast lumps. Ind J Surg. 1980;42:419-25.

25. Haagensen CD. Diseases of the breast. Philadelphia and London. WB Saunders, 1957.

26. Williams NS, Bulstrode CJK, O'Connell PR. The Breast. In: Bailey \& Love's short practice of surgery (25th edn.). Hodder Arnold. UK. 2008;50:827-48.

Cite this article as: Singh SK, Pankaj D, Kumar R, Mustafa R. A clinico-pathological study of malignant breast lump in a tertiary care hospital in Kosi region of Bihar. Int Surg J 2016;3:32-6. 